\title{
A T Cell View of the Bone Marrow
}

\author{
Adriana Bonomo ${ }^{1,2 *}$, Ana Carolina Monteiro², Triciana Gonçalves-Silva ${ }^{2,3}$, \\ Eric Cordeiro-Spinettit, Rômulo Gonçalves Galvani ${ }^{1,2,5}$ and Alex Balduino ${ }^{4,6}$
}

${ }^{1}$ Cancer Program (Fio-Cancer), Oswaldo Cruz Foundation, Rio de Janeiro, Brazil, ${ }^{2}$ Laboratory on Thymus Research, Oswaldo Cruz Institute, Oswaldo Cruz Foundation, Rio de Janeiro, Brazil, ${ }^{3}$ Immunology and Inflammation Graduate Program, Paulo de Góes Microbiology Institute, Federal University of Rio de Janeiro, Rio de Janeiro, Brazil, ${ }^{4}$ Cell Biology and Technology Laboratory, Veiga de Almeida University, Rio de Janeiro, Brazil, ${ }^{5}$ Microbiology Graduate Program, Paulo de Góes Microbiology Institute, Federal University of Rio de Janeiro, Rio de Janeiro, Brazil, ${ }^{6}$ Excellion Laboratory, Amil/UnitedHealth Group, Petrópolis, Brazil

The majority of $\mathrm{T}$ cells present in the bone marrow (BM) represent an activated/memory phenotype and most of these, if not all, are circulating T cells. Their lodging in the BM keeps them activated, turning the BM microenvironment into a "memory reservoir." This article will focus on how T cell activation in the BM results in both direct and indirect effects on the hematopoiesis. The hematopoietic stem cell niche will be presented, with its main components and organization, along with the role played by $T$ lymphocytes in basal and pathologic conditions and their effect on the bone remodeling process. Also discussed herein will be how "normal" bone mass peak is achieved only in the presence of an intact adaptive immune system, with $\mathrm{T}$ and $\mathrm{B}$ cells playing critical roles in this process. Our main hypothesis is that the partnership between $T$ cells and cells of the BM microenvironment orchestrates numerous processes regulating immunity, hematopoiesis, and bone remodeling.

Keywords: T cells, bone remodeling, hematopoiesis, B cells, osteoclast, osteoblast

The presence of $\mathrm{T}$ cells inside the bone marrow (BM) cavity has been reported mostly for central memory T cells (Tcm). It is suggested that hematopoietic stem cells (HSCs) niches serve as "hubs" for optimal $\mathrm{T}$ cell maintenance, as $\mathrm{T}$ cells can survive in the absence of antigen, in an environment rich in interleukin-7 (IL-7) and IL-15 (1), and other mediators believed to be important to T cell memory maintenance (2). Naive T cells can also be primed, get activated, and develop into effector cells inside the BM. Altogether, the BM can be seen as a primary lymphoid organ, which supports primary and secondary $\mathrm{T}$ cell responses (3). However, in the BM, the hematopoietic and the bone remodeling systems share the same microenvironment, together with $\mathrm{T}$ cells, which come from the periphery. These three components are maintained in equilibrium under homeostatic conditions. Nonetheless, when T cells are activated, this equilibrium is disrupted, and the result depends on the class of $\mathrm{T}$ cell response and its impact on hematopoiesis and bone remodeling.

The next sections will describe and discuss the interactions of BM T cells with the hematopoietic and bone remodeling systems. The first section starts describing the development and organization of the BM hematopoietic microenvironment, discussing the perivascular and endosteal niches and their players. In the second section, the role of $\mathrm{T}$ cell on shaping hematopoiesis and the correlation between the class of the adaptive response and type of innate immunity stimulated by specific $\mathrm{T}$ cells is presented as a cooperative ensemble. In the third section, $\mathrm{T}$ cell influence on bone remodeling is described, as well as the $\mathrm{T}$ cell-mediated interactions occurring either in physiological conditions or in two bone pathologies (arthritis and cancer metastasis). The main molecular axis that controls bone remodeling, RANK-RANK-L-OPG, is shared with T and B cells, and is discussed as the molecular basis for functional interaction between the skeletal and the adaptive immune systems. Finally, in 
the fourth section, $\mathrm{T}$ cell activities on both hematopoietic and bone remodeling systems are presented and the ability of $\mathrm{T}$ cells to orchestrate both systems is discussed according to the class of the response.

\section{HEMATOPOIETIC STEM CELL NICHE IN THE BM: CLOSE TO THE BONE SURFACE, NOT FAR FROM THE BLOOD VESSEL}

\section{Establishment of the HSC Niche in the BM}

During embryo development, first HSCs emerge in the blood islands in the extra-embryonic mesoderm of the yolk sac (4-6). Classified as a primitive population of HSCs; HSCs differentiate into nucleated erythrocytes and monocyte-like myeloid cells. In a second wave of hematopoiesis, termed definitive hematopoietic, HSCs emerge from the intra-embryonic mesoderm of the para-aortic-splanchnopleura/aorta-gonad-mesonephros (AGM) region. These cells, but not those derived from the yolk sac, are capable of fully reconstituting the BM of a lethally irradiated adult animal for 6 months or longer, indicating their definitive properties (4-8).

After blood circulation is established in the embryo, HSCs from both the yolk sac and the AGM region migrate and colonize the fetal liver. The fetal liver microenvironment is responsible for expanding the numbers of HSCs and promoting full commitment of the mesoderm-derived hematopoietic progenitors (9-13). Fetal liver HSC numbers progressively increase, prior to the migration of the hematopoietic system to the recently formed $\mathrm{BM}$ cavities. Once established in the BM cavity, most primitive hematopoietic progenitors and stem cells reside in the endosteal and subendosteal regions. Committed progenitors and differentiated cells derived from stem cells will then occupy the central and perisinusoidal regions of the BM cavity, respectively (Figure 1) (14-18).

The BM vasculature is composed of a dense network of blood vessels widely spread within the cavity. Along the bone diaphysis axis, the central artery carries in arterial blood to supply BM cells demand, while, in the same region, the central sinus carries out venous blood and differentiated hematopoietic cells into the blood circulation. Finer arteries and arterioles branch out from the central artery prior to reaching the endosteal surfaces, where they create a web-like structure to provide nutrients to the HSC niche (19-21). Conversely, sinusoidal blood venules cross the BM cavity and coalesce into wider veins as they drain into a central sinus. Approximately, one-fifth of all long-term HSCs in the BM, identified by the expression of CD150, c-Kit, and Sca-1, and absence of lineage markers, are found in close association with endosteal osteoblasts (18, 22-32) The remaining $80 \%$ dwell in the abluminal surface of the subendosteal sinusoids, interacting with pericytes and endothelial cells, both contributing to HSC self-renewal (28, 33-35). These data derived from different groups indicate that the niche formed by endosteal osteoblasts and the subendosteal sinusoidal perivascular cells coexist and are referred "quiescent niche" and "proliferative niche," respectively. In vitro and in vivo

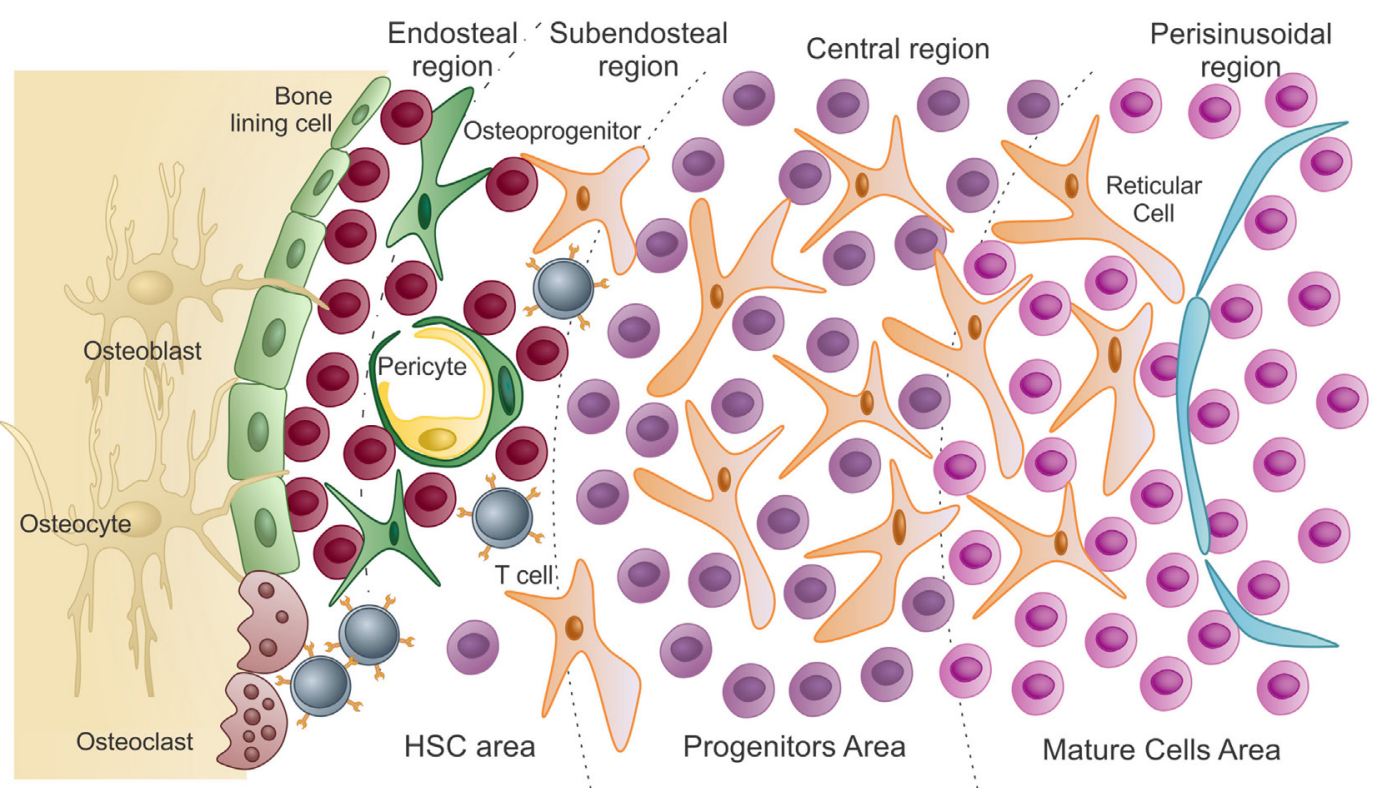

FIGURE 1 | Schematic presentation of the bone marrow microenvironment under "homeostatic" conditions. As previously described by Lambertsen and Weiss (15), HSC area, which harbors hematopoietic stem cells and uncommitted progenitors, comprises both endosteal and subendosteal niches. Committed progenitors and differentiated cells are distributed in the central and perisinusoidal niches, respectively. Quiescent hematopoietic stem cells are in close association with endosteal osteoblasts and bone-lining cells. As HSCs exit quiescence to proliferative states, they migrate and colonize the subendosteal perivascular niche, interacting with both endothelial cells and pericytes. Subendosteal sinusoid-derived pericytes serve as source for new osteoprogenitors, which will differentiate into osteoblasts during bone remodeling (adapted from Journal of Cellular Biochemistry, 2014, Cordeiro-Spinetti et al. with permission from John Wiley \& Sons). 
studies suggest that endosteal osteoblasts in the niche stimulate self-renewal and quiescence of the $\operatorname{HSC}(24,29,31,32,36,37)$. Such that in transgenic animals, increased or decreased numbers of osteoblasts result in increased or decreased numbers of long-term HSC, respectively, without affecting any of the other hematopoietic lineages in the $\mathrm{BM}(24,31,32,38)$. In situ observations show that most of the HSC population is concentrated in the trabecular bone zone, which also concentrates high numbers of osteoblasts, sinusoids, and CXCL12-positive pericyte-like cells $(35,39)$. In either case, HSCs are supported by highly expressing CXCL12-positive cells (40). The existence of the two niches remains controversial.

In the BM cavity, the microenvironment organization must match the hematopoietic system differentiation cascade, and each niche composition depends upon quality and number of specific types of stromal cell populations. Stromal cells comprise almost all non-hematopoietic cells found in the BM cavity - osteoblasts, endothelial cells, perivascular cells, mesenchymal cells, and nerve cells - which assemble in an organized network to physically and biologically properly support hematopoiesis $(16,18,23,24,32,41)$. Among all stromal cells, mesenchymal population represents around 90\%, including pericytes, mesenchymal stem cells (MSCs) and progenitors, perivascular cells, non-perivascular reticular cells, adventitial cells, and all types of myofibroblasts.

\section{Adaptive Immune Cells in the BM}

Translating the spatial organization of niches in conjunction with hematopoietic differentiation, it is conceivable that blood cell production follows a radial pattern within the BM cavity, with most primitive cells residing close to the bone surface and differentiated cells exiting the BM cavity through a central venous sinus $(15,16)$ (Figure 1). A few differentiated hematopoietic cells leave the BM cavity, circulate in the peripheral blood, differentiate inside other organs as $\mathrm{T}$ cells in the thymus, and then return to the BM cavity, migrating to specific niches and playing significant roles as "stromal cells." As such, T cells participate in a paracrine and juxtacrine signaling to contribute to hematopoiesis. $\mathrm{B}$ and $\mathrm{T}$ lymphocytes are among those cells with the ability to return to the $\mathrm{BM}$ after a quick trip to peripheral blood and lymphoid tissues. After BM cavity entering, memory B-lymphocytes, plasma cells, and $\mathrm{T}$ cells concentrate in the perivascular niche of subendosteal sinusoids (Figure 1). They will dwell in close association with CXCL12 highly producing cells, from where they produce and secrete cytokines to help maintain hematopoiesis homeostasis as we know it $(23,42-46)$.

Recirculating memory B-lymphocytes and active plasma cells secrete considerable levels of IL- 6 and TGF- $\beta$, contributing to a myelopoietic balance $(45,46)$. $\mathrm{CD}^{+} \mathrm{T}$ cells express CXCR4, which promotes their migration and colonization close to CXCL12 highly producing subendosteal sinusoid perivascular cells. CXCR4 expressing T cells provide substantial assistance to differentiating B-lymphocytes and produce membrane bound and secreted cytokines that regulate myelopoiesis $(42,45,46)$. Of note, recirculating $\mathrm{B}$ and $\mathrm{T}$ cells will colonize those niches identified as HSCs proliferative niche.

\section{Adipocytes in the BM}

Among those cells composing the stromal population, BM adipocytes apparently present the potential to contribute to both local and systemic metabolism $(47,48)$. BM adipose tissue (MAT) accumulation occurs during aging and other clinical conditions, including osteoporosis, diabetes, and gonadal dysfunction $(48,49)$, and interventions, such as chemotherapy and radiation $(47,49)$.

Osteoblasts, hematopoietic-supporting reticular cells, and BM adipocytes derive from a common precursor, named BM MSC, also known as skeletal stem cell or stromal stem cell (47-52). Clinical and histomorphometric studies have shown a correlation between MAT accumulation and decreased bone formation and increased bone loss (48), as hormones, corticoids, and local and peripheral factors might induce mesenchymal progenitors to follow the adipogenic differentiation path at the expense of the osteogenic one. Recent data, however, indicate that the hypothesis of a direct impact of MAT accumulation on skeletal tissue balance disruption is controversial, as adipocytes in the BM may present distinctive phenotypes, resembling either brown or white adipocytes, with potential different interactions with the skeletal tissue $(53,54)$.

Marrow adipose tissue accumulation and bone loss during aging and other conditions is usually accompanied by a decrease in HSCs number and blood cells production (55-59). In humans, when MAT areas mature in the yellow BM, adipocytes become densely packed and leave no room for active hematopoiesis (48, $60)$. In humans, yellow BM adipocytes appear at or right before birth, increasing up to the eighth week of age. Larger animals have more yellow BM as compared to smaller animals, which also extends farther into the bone cavities (60-63).

Adipocytes in the red BM do not become packed, but several findings implicate them as negative regulators of hematopoiesis. Adipocyte-derived soluble factors inhibit both B lymphopoiesis and granulopoiesis in vitro by blocking committed progenitors differentiation (64-67). When co-cultured with BM adipocytes, HSCs show reduced self-renewal capacity as compared to those co-cultured with other stromal cells $(23,68-71)$. In vivo, BM cavity areas rich in adipocytes most likely hold lower numbers of HSCs and short-term repopulating cells (72). Moreover, wild-type HSCs present enhanced repopulation ability when transplanted into animals with reduced numbers of $\mathrm{BM}$ adipocytes $(73,74)$. It was also observed that the balance between osteoblast and adipocyte differentiation influences hematopoietic recovery after irradiation. Hematopoietic precursor numbers increase when Runx 2 expression peaks and PPAR gamma expression decreases, suggesting that osteogenesis but not adipogenesis supports hematopoiesis (73). All data published so far support a negative effect of BM adipocytes in hematopoiesis, even though further investigation is definitely necessary.

In pathological conditions, primary or metastatic tumor cells can grow in the BM. In respect of the niches of tumor cells in the $\mathrm{BM}$, the role played by BM adipocytes is not clear yet. Apparently, BM adipocytes might secrete factors, which will modulate hematopoietic, immune, and tumor cells behavior in the niche. However, it is also very likely that the disruption in the osteoblast/ adipocyte differentiation balance results in a new combination of 
A

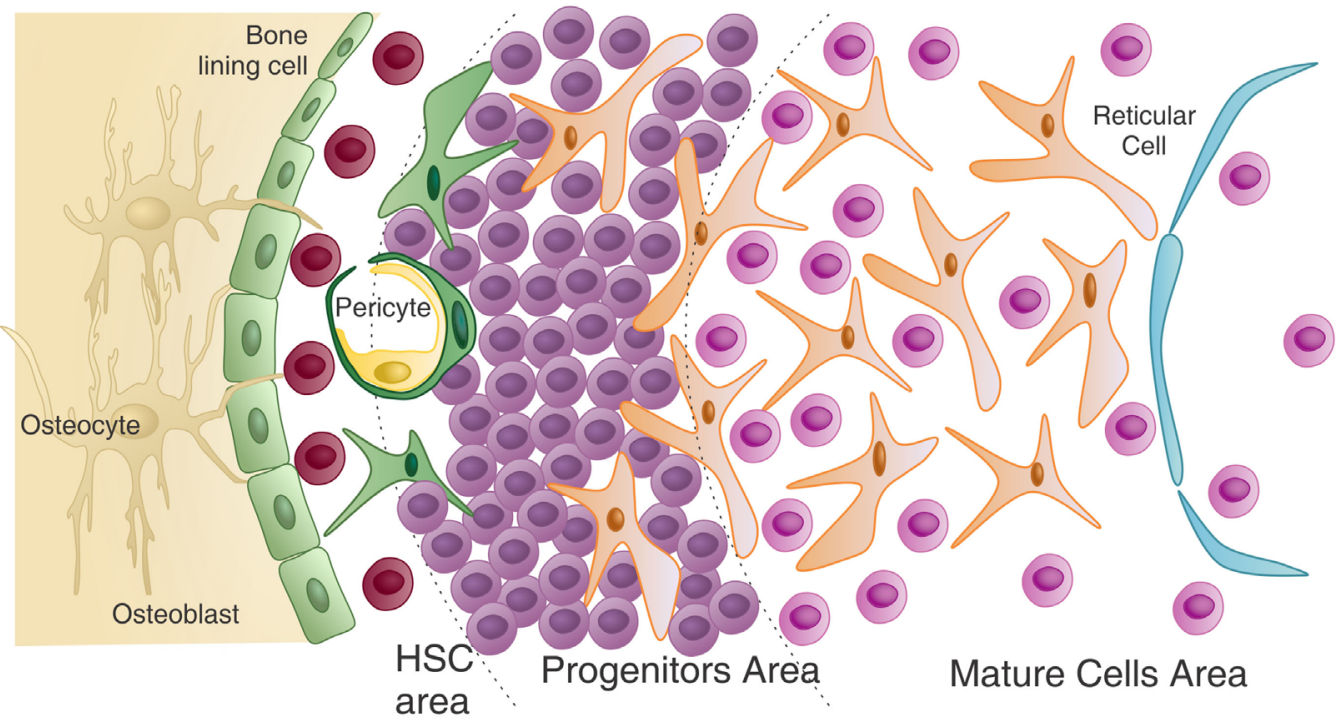

B

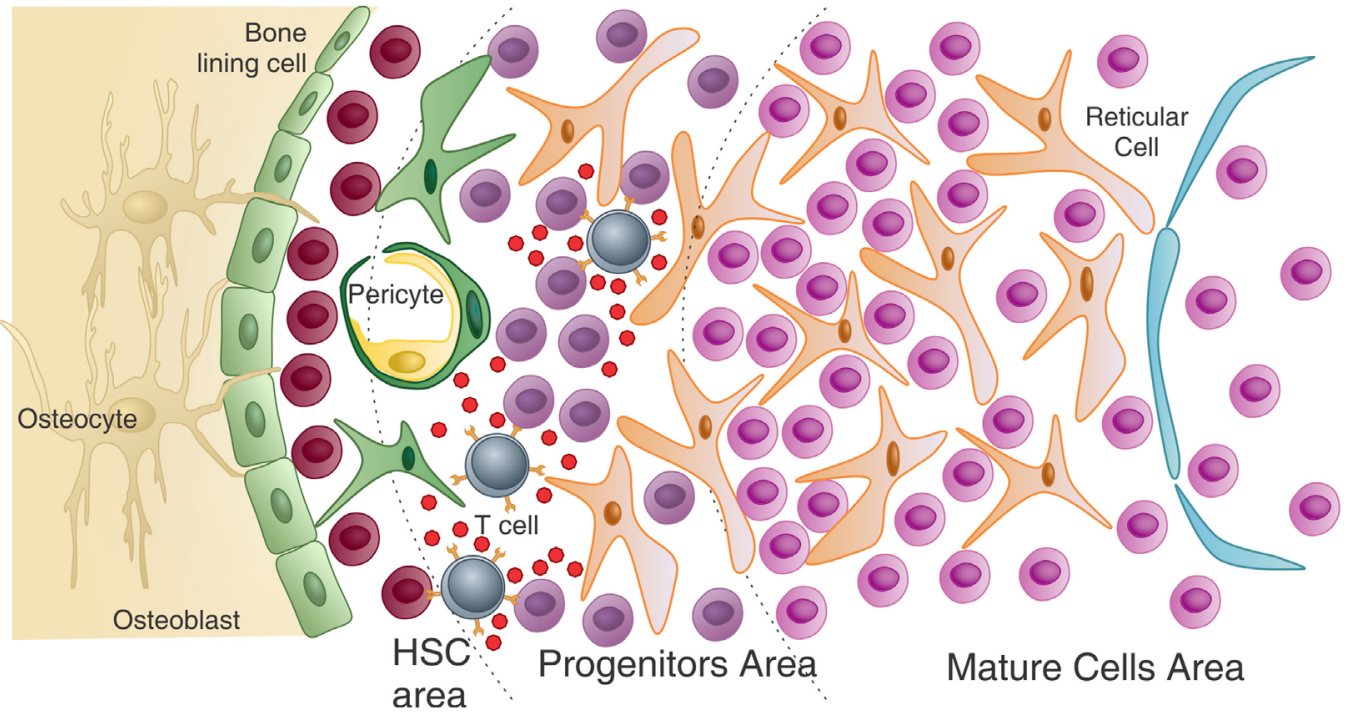

FIGURE 2 | T cells help normal hematopoiesis - (A) in the absence of T cells, or in the presence of non-activated T cells (not represented), immature progenitors cells, particularly of the myeloid lineage, accumulate in the bone marrow resulting in peripheral granulopenia. (B) When activated $T$ cells are present, they can see antigen in several hematopoietic cells and release growth factors, in return. These cytokines can directly and indirectly affect maturation of myeloid progenitors. Also, T cell cytokines modulate the stroma, which in turn can modulate HSC maintenance and myeloid differentiation. The number of HSC is also higher than in the T-less environment (adapted from Journal of Cellular Biochemistry, 2014, CordeiroSpinetti et al. with permission from John Wiley \& Sons).

stromal cells and formation of different categories of niches in the BM cavity.

\section{T CELL IN HEMATOPOIESIS: ORCHESTRATING THE PERIPHERAL DEMAND}

\section{T Cell Help Keeps "Normal" Hematopoiesis in the BM}

One of the first links between T lymphocytes and hematopoiesis emerges during development, and the relationship persists throughout life $(75,76)$. In vitro, it was shown that T cells could instruct splenic hematopoiesis in response to syngeneic stimulation (77). Also, patients receiving $\mathrm{T}$ cell depleted allogeneic BM transplantation have higher rates of graft failure $(78,79)$. Nonetheless, when $\mathrm{CD}^{+}$cells were co-administered with allogeneic BM stem cells, improvement and optimization of hematopoietic cells engraftment is observed (80).

Using athymic mice, our data suggest that $\mathrm{T}$ cell interactions with hematopoietic precursor populations maintain hematopoiesis. These athymic mice exhibit granulocytopenia in the peripheral blood, as immature granulocytes accumulate in the BM (Figure 2A). Importantly, immature hematopoietic 
cells in the BM have no intrinsic defect that prevents their differentiation, since in vitro stimulation with growth factors induces their differentiation and maturation. Thymus graft or $\mathrm{CD}^{+} \mathrm{T}$ cells' adoptive transfer, but not $\mathrm{CD}^{+} \mathrm{T}$ cells, rescues normal hematopoiesis and restores peripheral granulocytes counts. These $\mathrm{CD}^{+} \mathrm{T}$ lymphocytes present in the BM are predominantly activated and produce IL- 4 and IFN- $\gamma$, even in the absence of any intentional external antigen stimulation $(42,81)$. However, if $\mathrm{T}$ cells are virgin, meaning they have yet to interact with their cognate antigen (as in TCR transgenic mice specific for an external antigen), peripheral granulopenia with accumulation of myeloid blasts in the BM is observed (42). "Normal" hematopoiesis is restored, however, if $\mathrm{T}$ cells are activated with their cognate antigen (Figure 2B). This work demonstrates that, among its functions, $\mathrm{T}$ cell cross talk with hematopoiesis plays a critical role in "normal" hematopoiesis.

One critical demonstration of this relationship comes from studies with hyper IgM immunodeficiency patients. These patients have a mutation in the CD40L gene, and their activated T cells do not assist B cells and macrophages in their activities, even in the presence of cognate antigen (82-84). However, these patients are also granulopenic, suggesting that CD40L is also important for hematopoiesis. In fact, CD40L engagement induces the production of Flt3L by different cell types and thrombopoietin by BM stromal cells (85). Moreover, human CD34 ${ }^{+}$hematopoietic progenitor cell are CD40 positive and when CD40L binds to it, proliferation and myeloid differentiation take place, mainly on the dendritic cell (DC) pathway (86).

\section{BM In Situ Signaling and Delivery of Cytokines: T Cells Bring the News}

Studies on hematopoietic cells from the BM and the spleen of mice with diverse $\mathrm{T}$ helper cell polarization profiles provided clues on how $\mathrm{T}$ cells influence normal hematopoiesis. In mice with targeted deletion of STAT-4, which are biased to the Th2 phenotype, the number and cycling status of hematopoietic cells are significantly decreased compared to wild-type mice. By contrast, STAT-6 knockout mice, which are biased to Th1 response, demonstrate increased numbers of progenitors and cycling cells. This phenomenon is attributed to oncostatin M (OSM) secreted by Th1 T cells, since treatment of STAT-4-deficient mice with OSM recovers the number of cycling progenitors in the BM (87). From these observations, it becomes clear that activated BM T cells play an important role in hematopoiesis.

Further examples of T cells regulating hematopoiesis abound. For example Rådinger and colleagues $(88,89)$ reported that $\mathrm{CD}^{+} \mathrm{T}$ lymphocytes have a regulatory role in the control of eosinopoiesis in the BM. Transgenic mice overexpressing IL-5 in $\mathrm{CD}^{+}$cells and deficient in $\mathrm{CD} 8^{+}$cells show a significant decrease in $\mathrm{BM}$ eosinophils in steady state, what is not observed in the partner knockout mice to $\mathrm{CD}^{+}$. In addition, adoptive transfer of naive CD8 T lymphocytes into immunodeficient mice (SCID-bg) restores normal levels of eosinophils in the BM. By contrast, in airway allergen challenge both T CD4 and CD8 subsets seem to be important in BM and bronchoalveolar lavage (BAL) eosinophilia $(88,89)$. Another example of hematopoiesis regulation by $\mathrm{T}$ cells comes from adoptive transfer of activated antigen-specific
CD8 T lymphocytes, leading to increased numbers of multipotent and committed hematopoietic progenitor cells, especially myeloid lineage. These CD8 T cells secrete IFN- $\gamma$, which in turn acts on BM mesenchymal stromal cells, inducing these cells to release hematopoietic cytokines, especially IL-6. IL-6 modulates the expression of transcription factors essential to myeloid commitment and promotes accumulation of myeloid cells in the periphery (90).

Another molecule that implicates T lymphocytes in hematopoiesis is granulocyte macrophage colony-stimulating factor (GM-CSF). GM-CSF is a hematopoietic growth factor that stimulates proliferation of myeloid progenitor cells. It induces survival and activation of mature myeloid cells, and has a proinflammatory role in different diseases $(91,92)$. Interestingly, the hematopoietic system of GM-CSF knockout mice is normal (93). However, these mice when infected with Mycobacterium avium (94) or Listeria monocytogenes (95) have severe depletion of BM hematopoietic cell numbers, a deficient inflammatory response and are unable to increase their colony-forming cells in BM. This suggests that GM-CSF is essential for a hematopoietic response emergency, but not required for normal hematopoiesis. Interestingly, Th1 and Th17 lymphocytes are able to produce and secrete GM-CSF when activated by different stimuli (96-99). Recently, GM-CSF producing T cells (Th-GM) were reported. Generation of GM-CSF $/ \mathrm{IL}^{+} \mathrm{CD} 4$ lymphocytes is mediated by IL-7/STAT-5 signaling, and Th-GMs do not express the transcription factors T-bet and ROR- $\gamma$ t, suggesting that these cells belong to a distinct subset of Th cells $(100,101)$.

The effects of IL-17 in hematopoiesis appear to be largely indirect through the induction of cytokine secretion, including GM-CSF, G-CSF, SCF, NO, IL-6, prostaglandins, and other chemokines (102-104). BM stromal cells are the main target of IL-17 as stromal and MSCs, express a high level of IL-17RA (105, 106).

\section{Treg Inhibits Differentiation and Preserves the HSC Pool}

Recently, Treg lymphocytes involvement in hematopoiesis was investigated. The frequency of FoxP3 Treg cells in CD4 T cells is higher in the BM (around 20\%) than that in the spleen and lymph nodes $(10-15 \%)(107,108)$. Treg cells suppress the function of CD4 and CD8 T cells. In a murine model of allogeneic hematopoietic stem cell transplantation (HSCT) into non-irradiated recipients, Tregs co-localized with HSCTs and accumulated close to endosteum surface in the calvaria and trabecular BM. When Treg cells are depleted, a 70\% reduction in the number of surviving donor cells, with concomitant increase in levels of TNF- $\alpha$ and IL-4 producing CD4 ${ }^{+}$FoxP3 ${ }^{-}$and $\mathrm{CD}^{+}{ }^{+} \mathrm{T}$ BM cells is observed. These data suggest that Tregs provide an immune privilege mechanism that enables transplanted allo-HSPCs to escape allogeneic rejection in the BM (107). However, using a direct approach, Urbieta and colleagues (109) demonstrated that active Tregs are able to prevent the differentiation of IL-3/SCF colony-forming units (CFU) progenitor cells in vitro and this inhibition depends upon T cell antigen recognition and TGF- $\beta$, but not on FasL and perforin. Moreover, in syngeneic HSCT, Treg depletion either in host mice or in donor cell population increases 
splenic CFU-IL3 after transplantation indicating that donor and host Tregs can modulate hematopoiesis. In line with these results, addition of Tregs to T-cell-depleted transplants diminishes splenic and BM-derived CFU and peripheral neutrophil counts (109). It seems that Tregs indeed protect immature progenitors from differentiating and, most probably, help to keep the stem cell pool, although this deserves a more detailed investigation.

\section{Peripheral Demand and Central Hematopoiesis Holding Hands}

During infections and inflammatory conditions, immune effector cells, especially neutrophils, are highly demanded and rapidly consumed in peripheral tissues. Although adaptive immune cells ( $\mathrm{T}$ and $\mathrm{B}$ lymphocytes) respond to efficient antigen presentation with activation and proliferation, innate immune cells need to be replenished to maintain the progenitor cells pool. The hematopoietic response to this need is named demand-adapted hematopoiesis or emergency hematopoiesis.

T lymphocytes fit well with the definition of "messengers from the periphery to the BM" (Figure 2). The beauty of the system is that the pleiotropic effect of T cell interaction with multiple systems coordinates the immune response "class" in the adaptive as well as in the innate compartment. Th2 responses are the example prototype, with IL-4 being the master cytokine orchestrating the immune response. In the periphery, Th2 cells help B cells with a consequent switch in immunoglobulin class to IgE. In the BM, IL-4 induces mast cell differentiation. IgE has no function alone and works in pair with mast cells, made possible by the stimulation of IgE production by B cells and mast cells differentiation from BM progenitors, in a coordinated manner. Similar to this, Th1 responses induce IgG2a class switch in B cells and activate macrophages through IFN- $\gamma$, which inhibits osteoclast (OC) differentiation favoring the monocyte differentiation pathway (110). IgG2a is a good opsonin to which macrophages have highaffinity receptors. Th1 activity in the BM increases differentiation of monocytes, which have high-affinity receptors for IgG2a, and the immunoglobulin isotype is also stimulated by Th1 cells. In parallel to what was described above for Th2 cells, Th1 cells coordinate hematopoietic activity with adaptive immunity, with the immunoglobulin class switch improving innate immunity. Less obvious is the Th17 response, which is closely related to indirect actions, but signals on epithelial and stromal cells licensing those for production of cytokines, which will stimulate granulopoiesis and neutrophil migration to the damaged tissue. These cells are short lived and highly demanded, especially in the first phase of the response, needing to be replaced and produced in accelerated rates. This can be achieved after the Th17-specific cell engages its TCR on the surface of an antigen-presenting cell (APC) in the $\operatorname{BM}(42,111,112)$. Th17 cells secrete IL-17 and GM-CSF and stimulate BM stromal cells to produce G-CSF, modifying hematopoiesis based on antigen-specific peripheral demand.

There are still many points to be considered and investigated in the relationship between $\mathrm{T}$ lymphocytes and the hematopoietic system. However, the data gathered here provide strong evidence that this is not a simple and static relationship; it is modulated according to BM microenvironment, as well as by changes in the external environment sensed with the help of activated T cells.

\section{T CELL AND THE BONE: REGULATING THE BONE REMODELING SYSTEM}

\section{Bone Remodeling: The Players}

The skeletal system renews itself completely every 18 years, indicating its dynamic metabolism. Subendosteal perivascular cells serve as source for new osteoprogenitors in the BM cavity $(68,113,114)$. As bone remodels, several factors released from the matrix after OC-mediated bone resorption will recruit bonelining cells to become activate osteoblasts $(113,115)$. Osteoblasts will then deposit new bone matrix and further mineralize it. During bone deposition, a few osteoblasts get trapped in the matrix and become fully differentiated osteogenic cells, turning into osteocytes $(113,115)$.

Osteoclasts, on the other hand, derive from the hematopoietic lineage. OCs are bone resident cells involved in physiological and pathological remodeling of bone tissue. Mature OCs are tartrateresistant acid phosphatase (TRAP), calcitonin receptor, cathepsin $\mathrm{K}, \alpha \beta 3$-integrin, and adenosine triphosphate-dependent proton pump subunits positive, multinucleated giant cells that are generated from the fusion of precursors derived from the monocyte/ macrophage lineage (116). Mature OCs polarize and adhere to the bone matrix, acidify the bone surface, release osteolytic enzymes, and resorb bone. Two factors appear as crucial for OC differentiation: macrophage colony-stimulating factor (M-CSF), which induces monocyte differentiation, and RANKL, which is essential for stimulating pre-OC differentiation and its merge into multinucleated cells. Both factors are believed to derive mainly from osteoprogenitor cells and pre-osteoblast. Osteoblasts, on the other hand, produce and secrete osteoprotegerin (OPG) that is a RANK decoy receptor and inhibits OC formation and bone resorption (116).

Under physiological conditions, the balance between bone formation and resorption is finely tuned and can be disrupted under non-homeostatic conditions (Figure 3A).

\section{RANK-RANKL-OPG Axis: Linking the Immune and Skeletal System}

RANKL (also known as ODF, TRANCE, OPGL, and TNFSF11) and its receptor RANK (also known as TRANCE-R and TNFRSF11A) central players in bone metabolism (117) were first described as molecules expressed in T cells and DCs. OPG, the soluble receptor/antagonist for RANKL, initially characterized as an inhibitor factor of OC development and bone resorption, expressed by osteoblasts $(116,118)$, and B cells $(119,120)$, has also been described as a crucial regulator of $\mathrm{B}$ cell maturation and development of antibody responses (121). In fact, the RANK/ RANKL system also controls lymph node organogenesis and development of thymic medullary epithelial cells and lymphocytes (122-124). The RANK-RANKL-OPG axis also has important functions in other systems, such as the lactating breast, and in the thermo-regulatory system (125). Regulation of tumor cell migration to the bone as well as primary mammary tumor growth had also been reported and relate to physiological activities of these molecules (126).

The role of the adaptive immune system in what is known as the equilibrium between bone consumption and deposition in 

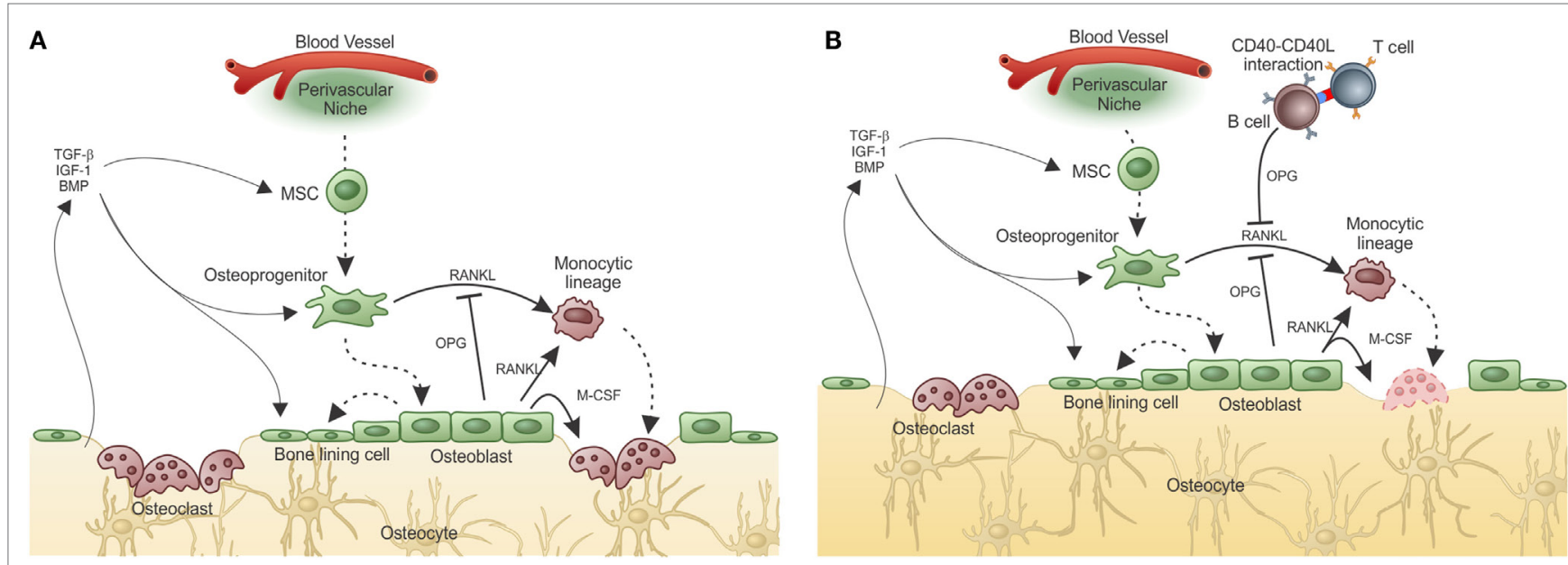

FIGURE 3 | Adaptive immunity participates in physiological bone remodeling - (A) bone remodeling relies on osteoclasts (OC), which in physiological situations differentiate from $O C$ precursors of the monocytic lineage after signaling through RANK in its surface and RANKL produced by osteoprogenitor cells. As the bone is resorbed, growth factors and other molecules stored in the extracellular matrix are released, including TGF- $\beta$ that stimulates osteoblastogenesis from MSC, which reside in the perivascular niche (as in the representation) or in the endosteal niche (not represented). As a consequence, new osteoblasts are formed resulting in bone formation. OPG, a decoy receptor for RANKL, is produced by osteoblasts and participate modulating the bone remodeling system. (B) When activated T cells are present, they activate B cells in a CD40-CD40L-dependent manner with OPG production in large quantities by B cells. This leads to bone accumulation as the RANK-RANKL axis is disrupted by the high amounts of OPG produced by B cells. This is what defines the "normal" bone mass in physiological situation, in SPF condition. Dashed lines represent cellular differentiation; filled line represents cytokine action.

healthy animals was addressed by Li et al. (119). They showed that acquisition of normal bone mass depends on the presence of OPG produced by mature activated B cells. However, in the absence of T cells, B cells do not produce OPG and bone remodeling is unbalanced toward bone consumption due to lack of the inhibitory OPG-RANKL loop. Moreover, OPG production by $B$ cells was dependent upon CD40L from activated T cells, showing that T-B interaction is required for "normal" bone density maintenance (Figure 3B).

Evidence related to hormonal (estrogen) regulation of TNF- $\alpha$ production by $\mathrm{T}$ cells have also been published, and data link adaptive immunity to bone activity (127). However, the results vary depending on the model used (128). In the presence of $\mathrm{B}$ cells, but in the absence of $\mathrm{T}$ cells, bone mass decreases after ovariectomy, in accordance to Li et al. (119). In this case, B cells are present, but are not activated by $\mathrm{T}$ cells. However, if both, $\mathrm{B}$ and $\mathrm{T}$ cells are absent, as in RAG-deficient mice, bone mass increases after ovariectomy making any conclusion about the role of estrogen in regulation of $\mathrm{T}$ cell activity over the bone difficult at the present moment.

Apart from hormones, another important evidence of $\mathrm{T}$ cell participation in physiological bone remodeling comes from studies in germ-free (GF) mice $(127,129)$. These animals have lower numbers of $\mathrm{T}$ cells in the BM and these are not activated. Also, GF mice have low frequency of OCs and are osteopetrotic. Coincidentally, colonization with commensal microbiota reverses the osteopetrotic phenotype and restores normal numbers of activated T cells, as well as of OC precursors (130) These data are in accordance with the view that in steady-state healthy conditions, recognition of antigen by $\mathrm{T}$ cells tunes the bone remodeling system.
T-cell-derived RANKL can contribute to bone loss in some pathological conditions, as it was first proposed by Kong and colleagues in a model of inflammatory bone disease (131). Later studies showing reversal of RANKL-dependent osteopetrosis by hyper-expression of RANKL in T and B cells (132) reinforced the interplay between adaptive immune cell-derived RANKL and bone metabolism. On the other hand, Sato et al. better described the involvement of T-cell-derived IL-17A and interaction with RANKL in synoviocyte and macrophages in the inflamed joint $(133,134)$.

Generally, the cross talk between both systems has been studied in models of arthritis, in which the action of T cells in an inflamed joint stimulates osteoclastogenesis and bone resorption through the indirect action of T-cell-derived IL-17A and RANKL (134-137). However, in the arthritis models, T cells reach the bone through the articular cavity after an inflammatory injury, which destroys the cartilage and exposes the periosteal bone surface.

In contrast to these mechanisms observed in arthritis, in other conditions, the $\mathrm{T}$ cells normally present inside the $\mathrm{BM}$ and in contact with the bone might contribute to pathological bone remodeling. In fact, we have recently shown that RANKL production by tumor-primed $\mathrm{BM} \mathrm{CD} 4^{+} \mathrm{T}$ cells induces pre-metastatic osteolytic bone disease that licenses metastatic colonization (138). We reached this conclusion by showing that the $4 \mathrm{~T} 1$ breast tumor induces production of pro-osteoclastogenic cytokines, IL-17F, and RANKL by BM CD4 ${ }^{+} \mathrm{T}$ cells, leading to OC formation and activation in vitro and in vivo. Surprisingly, osteolytic disease was observed even before tumor cells colonized the bone and was induced by $\mathrm{T}$ cell transfer, showing that $\mathrm{T}$ cells prepare the metastatic niche for further establishment of tumor cells 
(Figure 4A). Thus, the T cell mediated pre-metastatic osteolytic disease adds an extra step to the vicious cycle hypothesis, which established that bone colonization by tumor cells culminate in the release of growth factors from the bone matrix as a consequence of OC activity (Figure 4B) $(139,140)$.

\section{Osteoclasts and Dendritic Cells: Modulators of the Bone Remodeling Gear}

Interactions between monocytes/macrophages and OCs has long been studied and was appreciated in the pioneering work of Horton et al. in the early 1970s (141). The set of soluble factors secreted from antigen-stimulated peripheral blood mononuclear cells was initially described as an "OC-activating factor," which subsequently was identified as predominantly interleukin-1 (IL-1) and TNF (142). In addition, numerous macrophagederived cytokines influence OC differentiation and/or function, such as M-CSF, which are essential for the development and survival of the monocyte/macrophage lineage as well as OC differentiation (136).

One important cell type also derived from monocytic progenitors and precursors in the BM is the DC, the most potent APC, responsible for activating naive $\mathrm{T}$ cells, and orchestrating the immune responses (143). Since DCs are derived from the same monocyte/macrophage OC precursor lineage, it is not surprising that splenic immature DCs can be developed into OCs (OC-DC), when cultured with osteoclastogenic factors M-CSF and RANKL (144-146).

Accumulated evidence indicates that mature OCs can function as APCs to both $\mathrm{CD}^{+}$and $\mathrm{CD}^{+} \mathrm{T}$ cells in vitro. They express MHC I and II, CD80, CD86, CD40, IL-10, TGF- $\beta$, IL-6, and TNF- $\alpha$, all molecules that act on T cell activation and class switch (147). It has been suggested that the monocyte population used to differentiate OCs carry contaminant DCs or monocyte themselves, which could explain the antigen-presenting capabilities of
OCs. OCs can in fact be derived from immature DCs in vivo and in vitro (148-150), although the antigen-presenting capability of these OC-DCs had never been addressed.

Circulating DCs are normally recruited to inflamed tissues (149, 151) and IL-23-producing DCs play an indirect role in osteoclastogenesis by stimulating $\mathrm{T}$ cell expression of RANKL and IL-1, IL-6, IL-17, and TNF- $\alpha$ that augment the release of TRAP and cathepsin K by resident OCs (149). A still-open question is whether the same growth factors that control normal osteoclastogenesis are also involved in generating OCs in response to inflammation with potent DC activity. Participation of OC-DC in bone remodeling was suggested in Langerhans cell histiocytosis (LCH). $\mathrm{LCH}$ is a multi-symptom disease with associated bone resorption and granuloma formation, and soft tissue inflammatory lesions (152). Bone pathology appears to rely on DCs and monocytes, which produce high levels of IL-17A and induce DC-OC differentiation $(150,153)$. Also it was shown that DCs could induce osteolysis when transferred to regular or osteopetrotic mice (154). Osteolytic activity in vivo was inhibited with OPG and bisphosphonates, implying a role for RANKL in the pathogenic DC-OC pathway (154).

Since it was shown that $\mathrm{DC}$ can prime $\mathrm{T}$ cells inside the $\mathrm{BM}$ (155), it can be reasoned that a DC can acquire OC characteristics while keeping its antigen-presenting capabilities. If this is true, then DCs can work as messengers from the periphery to the BM where they maintain $\mathrm{T}$ cell activation/memory and interfere with bone metabolism, in addition to participating in hematopoiesis (Figure 5).

\section{FINAL REMARKS: TUNING THE BM MULTISYSTEM}

The skeletal system provides vital functions, as mechanical structure, movement, protection, calcium storage, endocrine
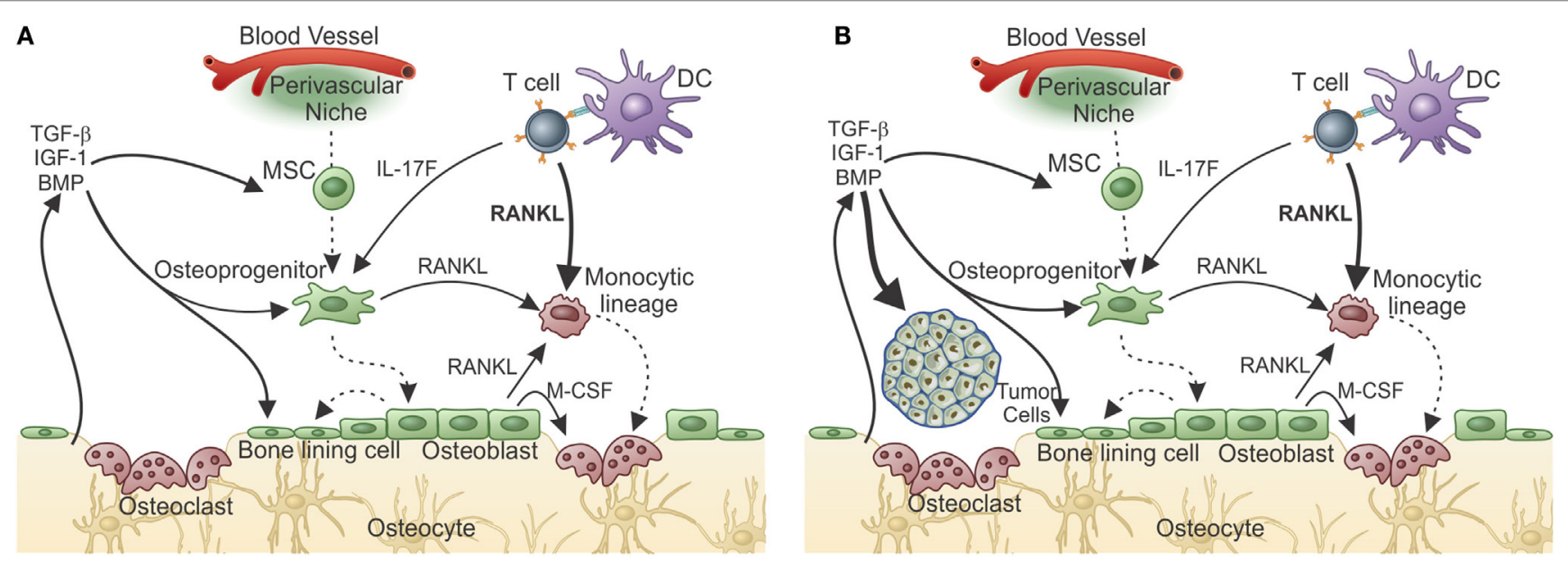

FIGURE 4 | T-cell-derived RANKL prepares the bone pre-metastatic niche. (A) After responding T cells meet tumor antigen and get activated, they migrate to the bone marrow where, after encountering antigen, they release cytokines. In the case of a metastatic tumor, responding $T$ cells produce IL-17 and RANKL. Although IL-17F from T cells can indirectly influences osteoclastogenesis, T-cell-derived RANKL is the central cytokine stimulating osteoclastogenesis and bone consumption resulting in pre-metastatic niche organization with growth factor release from the resorbed matrix. (B) The growth factor-rich environment will nourishes the arriving tumor cells allowing metastatic colonization. In the absence of T-cell-derived RANKL, metastatization into the bone does not take place. 

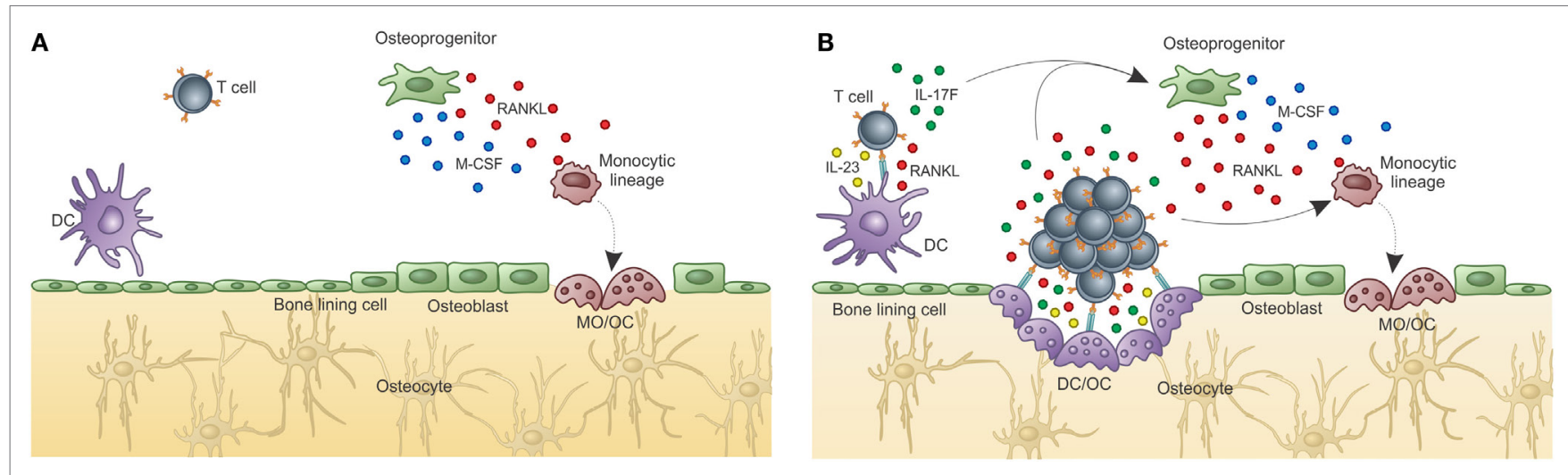

FIGURE 5 | Osteoclasts are optimal antigen-presenting cells when derived from DCs, but not from BM progenitors. Osteoclasts are usually derived from bone marrow progenitors or monocytic precursors (OC), but can also derive from dendritic cells under certain conditions (OC-DC). (A) Classical "constitutive" OC. $\mathrm{OC}$ are not good antigen presenters, cannot activate T cells, and do not maintain T cell activation in the BM. Thus, OCs do not contribute to T cell activation in the BM. (B) Activation induced OC-DC. Under the influence of RANKL among other cytokines, OC-DCs are induced. If OC-DCs are as good as fresh DCs in presenting antigen to T cells and if they provide IL-23, a positive loop will be built, which can amplify the osteoclastogenic potential of T cell stimulation. In this context, the bone-resorbing activity of both DC-OC and classical OC will result in decreased bone mass (represented by the light color of the matrix). Whether both OCs dwells in the same resorbing pit, or are segregated into separate subniches, as represented in B, is unknown.

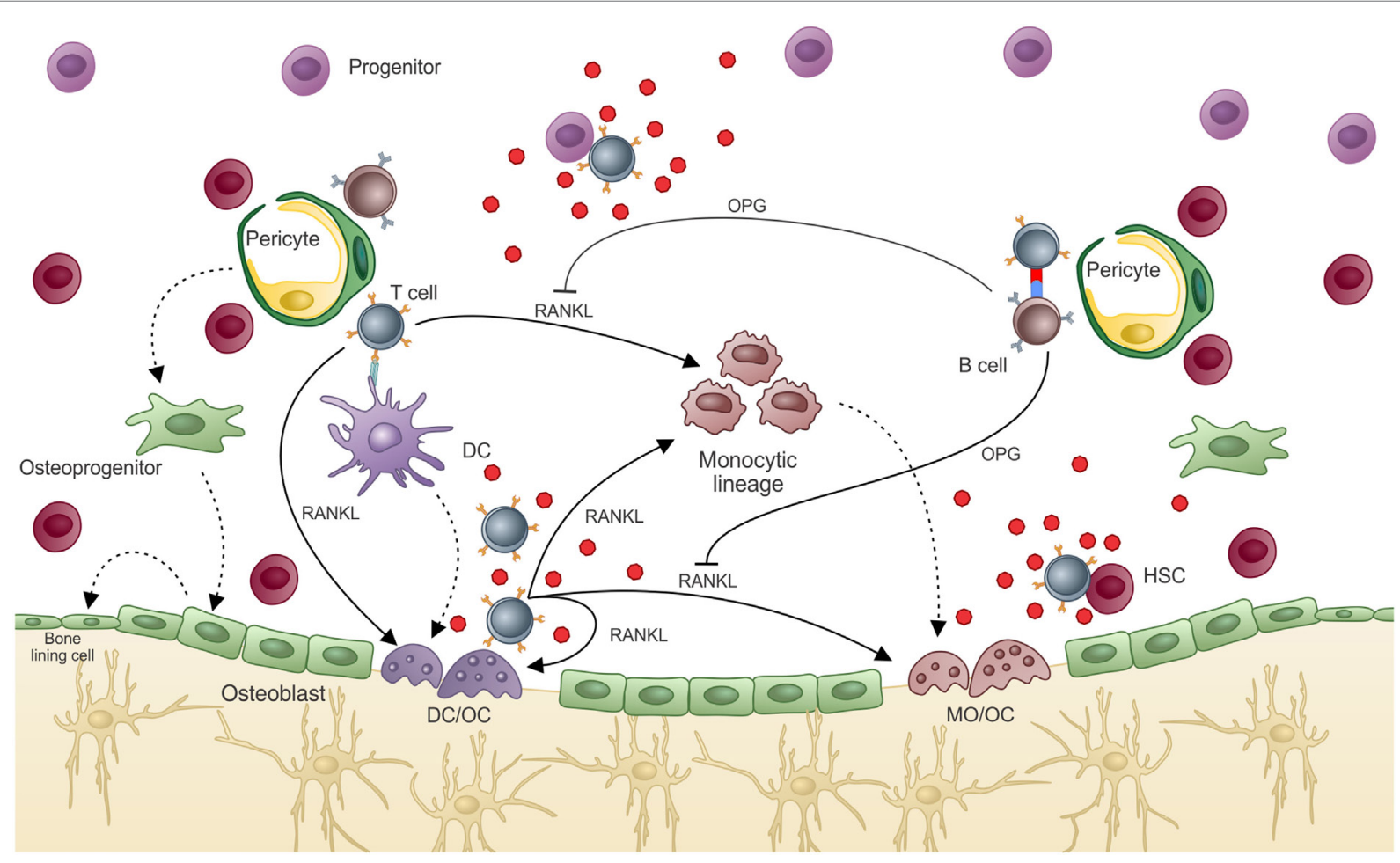

FIGURE 6 | T cell regulation of bone marrow environment. T cell participation in the BM environment promotes what we know as "normal hematopoiesis" and "normal bone mass." In hematopoiesis, T cell release of hematopoietic cytokines after activation allows terminal differentiation of hematopoietic progenitors/ precursors, which will compose the "normal" peripheral pool. "Normal" bone density is also dependent on T cell activation, which in a normal state activates B cells to produce OPG, balancing bone resorption by OCs and mineral deposition by OBs. If T cells are highly activated or are turned into an osteoclastogenic phenotype, excessive bone resorption can lead to osteolytic disease. Moreover, some of the cytokines produced by $T$ cells that can interfere with the bone remodeling system can also affect hematopoiesis, such as IL-17F.

regulation, and support for the whole hematopoietic system. Blood cell production is a very finely controlled process, which depends upon stromal cells and their factors, and cell intrinsic conditions. In the BM cavity, HSCs and progenitors reside close to the bone surfaces, which suggests that the two systems are integrated. 
Bone remodeling's influence over hematopoiesis is not clear, although there are reports in the literature, indicating that osteoblast activity increases the number of primitive progenitors (24, $31,32,38)$ and also that increased numbers of OCs might induce HSC mobilization $(28,32,115,156-158)$. It is possible that OC mobilization and activation together disrupt HSC niches as the stem cells reside close to the bone surface and in close contact to osteoblasts. As both OCs and OBs are involved in bone remodeling, stem cell niches are disrupted and the immature progenitors leave the quiescent niche and are enabled to enter the proliferation and differentiation pathway. $T$ cells participate on maintaining or disrupting the balance of both systems depending on their activity. In the case of pro-osteolytic activity, when $\mathrm{T}$ cells get inside the BM, they can see antigen on IL- $23^{+} \mathrm{DCs}$, keeping their Th17 profile, producing RANKL and inducing osteolysis. This will disrupt hematopoiesis through osteoclastogenesis stimulation, which disturbs the HSC niche. At the same time, T cells can produce IL-17A, F, and G-CSF $(98,99)$, which indirectly stimulates neutrophil maturation, providing "help" for the immature myeloid progenitors recently released from the stem cell niche.

In summary, we believe that $\mathrm{T}$ cells pave the road that unravels the partnership of the three systems (i.e., immunity, hematopoiesis, bone homeostasis) by acting as messengers from the periphery to the bone cavity. It is clear that inside the BM, T cells bring information from the periphery. They produce cytokines and express membrane molecules, which will act in an antigen-specific manner. Although it remains unclear as to the need for a cognate antigen inside the $\mathrm{BM}$, it is clear that only after in vivo priming can BM T cells acquire an activated

\section{REFERENCES}

1. Mazo IB, Honczarenko M, Leung H, Cavanagh LL, Bonasio R, Weninger W, et al. Bone marrow is a major reservoir and site of recruitment for central memory CD8+ $\mathrm{T}$ cells. Immunity (2005) 22:259-70. doi:10.1016/j. immuni.2005.01.008

2. Sabbagh L, Snell LM, Watts TH. TNF family ligands define niches for T cell memory. Trends Immunol (2007) 28:333-9. doi:10.1016/j.it.2007.06.001

3. Di Rosa F, Pabst R. The bone marrow: a nest for migratory memory T cells. Trends Immunol (2005) 26:360-6. doi:10.1016/j.it.2005.04.011

4. Godin I, Cumano A. The hare and the tortoise: an embryonic haematopoietic race. Nat Rev Immunol (2002) 2:593-604. doi:10.1038/nri857

5. Ikuta K, Weissman IL. Evidence that hematopoietic stem cells express mouse c-kit but do not depend on steel factor for their generation. Proc Natl Acad Sci U S A (1992) 89:1502-6. doi:10.1073/pnas.89.4.1502

6. Moore MA, Metcalf D. Ontogeny of the haemopoietic system: yolk sac origin of in vivo and in vitro colony forming cells in the developing mouse embryo. Br J Haematol (1970) 18:279-96. doi:10.1111/j.1365-2141.1970. tb01443.x

7. Cumano A, Ferraz JC, Klaine M, Di Santo JP, Godin I. Intraembryonic, but not yolk sac hematopoietic precursors, isolated before circulation, provide long-term multilineage reconstitution. Immunity (2001) 15:477-85. doi:10.1016/S1074-7613(01)00190-X

8. Medvinsky A, Dzierzak E. Definitive hematopoiesis is autonomously initiated by the AGM region. Cell (1996) 86:897-906. doi:10.1016/ S0092-8674(00)80165-8

9. Christensen JL, Wright DE, Wagers AJ, Weissman IL. Circulation and chemotaxis of fetal hematopoietic stem cells. PLoS Biol (2004) 2:E75. doi:10.1371/ journal.pbio.0020075

10. Ema H, Nakauchi H. Expansion of hematopoietic stem cells in the developing liver of a mouse embryo. Blood (2000) 95:2284-8. phenotype. Whether or not $\mathrm{T}$ cell regulation of bone homeostasis requires recognition of self-antigens by DCs or OCs inside the $\mathrm{BM}$, or if antigen-loaded APCs do the job or both, is still not clear. However, it is clear that if BM T cells recognize antigen (self or not) on APCs, they will exert their effector functions "helping" the bone remodeling and hematopoietic system. The final effect on hematopoiesis and bone remodeling depends on the class of the $\mathrm{T}$ cell response (159), identified by the cytokine package produced and released by the $\mathrm{T}$ cell subset (Figure 6).

\section{AUTHOR CONTRIBUTIONS}

$\mathrm{ABo}, \mathrm{AM}, \mathrm{TG}-\mathrm{S}$ discussed the literature anrd wrote about $\mathrm{T}$ cells inside the bone marrow; EC-S and ABa discussed and wrote about the bone marrow organization and its niches. RG prepared the illustrations, discussed and reviewd the paper. $\mathrm{ABo}$ and $\mathrm{ABa}$ revised and put together the niches, in the bone marrow and the adaptive immune system.

\section{ACKNOWLEDGMENTS}

We must thank Professor Russell S. Taichman for his suggestions and provocative discussions to enrich the present manuscript.

\section{FUNDING}

This work was funded by Fundação Carlos Chagas Filho de Amparo à Pesquisa do Estado do Rio de Janeiro, grants \#E_26/204.481/2014; E_26/112.898/2012 and Conselho Nacional de Desenvolvimento Científico e Tecnológico 483385/2013-1; 309755/2014-0.

11. Inlay MA, Serwold T, Mosley A, Fathman JW, Dimov IK, Seita J, et al Identification of multipotent progenitors that emerge prior to hematopoietic stem cells in embryonic development. Stem Cell Rep (2014) 2:457-72. doi:10.1016/j.stemcr.2014.02.001

12. Kieusseian A, Brunet de la Grange P, Burlen-Defranoux O, Godin I, Cumano A. Immature hematopoietic stem cells undergo maturation in the fetal liver. Development (2012) 139:3521-30. doi:10.1242/dev. 079210

13. Morrison SJ, Hemmati HD, Wandycz AM, Weissman IL. The purification and characterization of fetal liver hematopoietic stem cells. Proc Natl Acad Sci U S A (1995) 92:10302-6. doi:10.1073/pnas.92.22.10302

14. Cordeiro-Spinetti E, Taichman RS, Balduino A. The bone marrow endosteal niche: how far from the surface? J Cell Biochem (2015) 116:6-11. doi:10.1002/ jcb. 24952

15. Lambertsen RH, Weiss L. A model of intramedullary hematopoietic microenvironments based on stereologic study of the distribution of endocloned marrow colonies. Blood (1984) 63:287-97.

16. Lord BI, Testa NG, Hendry JH. The relative spatial distributions of CFUs and CFUc in the normal mouse femur. Blood (1975) 46:65-72.

17. Nilsson SK, Simmons PJ. Transplantable stem cells: home to specific niches. Curr Opin Hematol (2004) 11:102-6. doi:10.1097/01.moh.0000133651. $06863.9 \mathrm{c}$

18. Taichman RS. Blood and bone: two tissues whose fates are intertwined to create the hematopoietic stem-cell niche. Blood (2005) 105:2631-9. doi:10.1182/ blood-2004-06-2480

19. Fei J, Jia F, Peyrin F, Françoise P, Malaval L, Vico L, et al. Imaging and quantitative assessment of long bone vascularization in the adult rat using microcomputed tomography. Anat Rec (Hoboken) (2010) 293:215-24 doi:10.1002/ar.21054

20. Nombela-Arrieta C, Pivarnik G, Winkel B, Canty KJ, Harley B, Mahoney JE, et al. Quantitative imaging of haematopoietic stem and progenitor cell 
localization and hypoxic status in the bone marrow microenvironment. Nat Cell Biol (2013) 15:533-43. doi:10.1038/ncb2730

21. Skawina A, Litwin JA, Gorczyca J, Miodoński AJ. The vascular system of human fetal long bones: a scanning electron microscope study of corrosion casts. J Anat (1994) 185(Pt 2):369-76.

22. Arai F, Hirao A, Ohmura M, Sato H, Matsuoka S, Takubo K, et al. Tie2/ angiopoietin-1 signaling regulates hematopoietic stem cell quiescence in the bone marrow niche. Cell (2004) 118:149-61. doi:10.1016/j.cell.2004.07.004

23. Balduino A, Mello-Coelho V, Wang Z, Taichman RS, Krebsbach PH, Weeraratna AT, et al. Molecular signature and in vivo behavior of bone marrow endosteal and subendosteal stromal cell populations and their relevance to hematopoiesis. Exp Cell Res (2012) 318:2427-37. doi:10.1016/j. yexcr.2012.07.009

24. Calvi LM, Adams GB, Weibrecht KW, Weber JM, Olson DP, Knight MC, et al. Osteoblastic cells regulate the haematopoietic stem cell niche. Nature (2003) 425:841-6. doi:10.1038/nature02040

25. Kiel MJ, Iwashita T, Yilmaz OH, Morrison SJ. Spatial differences in hematopoiesis but not in stem cells indicate a lack of regional patterning in definitive hematopoietic stem cells. Dev Biol (2005) 283:29-39. doi:10.1016/j. ydbio.2005.03.037

26. Kiel MJ, Radice GL, Morrison SJ. Lack of evidence that hematopoietic stem cells depend on $\mathrm{N}$-cadherin-mediated adhesion to osteoblasts for their maintenance. Cell Stem Cell (2007) 1:204-17. doi:10.1016/j. stem.2007.06.001

27. Nilsson SK, Johnston HM, Coverdale JA. Spatial localization of transplanted hemopoietic stem cells: inferences for the localization of stem cell niches. Blood (2001) 97:2293-9. doi:10.1182/blood.V97.8.2293

28. Song J, Kiel MJ, Wang Z, Wang J, Taichman RS, Morrison SJ, et al. An in vivo model to study and manipulate the hematopoietic stem cell niche. Blood (2010) 115:2592-600. doi:10.1182/blood-2009-01-200071

29. Taichman RS, Emerson SG. The role of osteoblasts in the hematopoietic microenvironment. Stem Cells (1998) 16:7-15. doi:10.1002/stem.160007

30. Taichman R, Reilly M, Verma R, Ehrenman K, Emerson S. Hepatocyte growth factor is secreted by osteoblasts and cooperatively permits the survival of haematopoietic progenitors. Br J Haematol (2001) 112:438-48. doi:10.1046/j.1365-2141.2001.02568.x

31. Visnjic D, Kalajzic Z, Rowe DW, Katavic V, Lorenzo J, Aguila HL. Hematopoiesis is severely altered in mice with an induced osteoblast deficiency. Blood (2004) 103:3258-64. doi:10.1182/blood-2003-11-4011

32. Zhang J, Niu C, Ye L, Huang H, He X, Tong W-G, et al. Identification of the haematopoietic stem cell niche and control of the niche size. Nature (2003) 425:836-41. doi:10.1038/nature02041

33. Boulais PE, Frenette PS. Making sense of hematopoietic stem cell niches. Blood (2015) 125:2621-9. doi:10.1182/blood-2014-09-570192

34. Kunisaki Y, Bruns I, Scheiermann C, Ahmed J, Pinho S, Zhang D, et al. Arteriolar niches maintain haematopoietic stem cell quiescence. Nature (2013) 502:637-43. doi:10.1038/nature12612

35. Morrison SJ, Scadden DT. The bone marrow niche for haematopoietic stem cells. Nature (2014) 505:327-34. doi:10.1038/nature12984

36. Taichman RS, Emerson SG. Human osteoblasts support hematopoiesis through the production of granulocyte colony-stimulating factor. J Exp Med (1994) 179:1677-82. doi:10.1084/jem.179.5.1677

37. Taichman RS, Reilly MJ, Emerson SG. Human osteoblasts support human hematopoietic progenitor cells in vitro bone marrow cultures. Blood (1996) 87:518-24.

38. Kuznetsov SA, Riminucci M, Ziran N, Tsutsui TW, Corsi A, Calvi L, et al. The interplay of osteogenesis and hematopoiesis: expression of a constitutively active PTH/PTHrP receptor in osteogenic cells perturbs the establishment of hematopoiesis in bone and of skeletal stem cells in the bone marrow. J Cell Biol (2004) 167:1113-22. doi:10.1083/jcb.200408079

39. Bourke VA, Watchman CJ, Reith JD, Jorgensen ML, Dieudonnè A, Bolch WE. Spatial gradients of blood vessels and hematopoietic stem and progenitor cells within the marrow cavities of the human skeleton. Blood (2009) 114:4077-80. doi:10.1182/blood-2008-12-192922

40. Greenbaum A, Hsu Y-MS, Day RB, Schuettpelz LG, Christopher MJ, Borgerding JN, et al. CXCL12 in early mesenchymal progenitors is required for haematopoietic stem-cell maintenance. Nature (2013) 495:227-30. doi:10.1038/nature11926
41. Ding L, Saunders TL, Enikolopov G, Morrison SJ. Endothelial and perivascular cells maintain haematopoietic stem cells. Nature (2012) 481:457-62. doi:10.1038/nature10783

42. Monteiro JP, Benjamin A, Costa ES, Barcinski MA, Bonomo A. Normal hematopoiesis is maintained by activated bone marrow CD4+ T cells. Blood (2005) 105:1484-91. doi:10.1182/blood-2004-07-2856

43. Nemoto Y, Kanai T, Makita S, Okamoto R, Totsuka T, Takeda K, et al. Bone marrow retaining colitogenic $\mathrm{CD} 4+\mathrm{T}$ cells may be a pathogenic reservoir for chronic colitis. Gastroenterology (2007) 132:176-89. doi:10.1053/j. gastro.2006.10.035

44. Slifka MK, Matloubian M, Ahmed R. Bone marrow is a major site of longterm antibody production after acute viral infection. J Virol (1995) 69: 1895-902.

45. Tokoyoda K, Egawa T, Sugiyama T, Choi B-I, Nagasawa T. Cellular niches controlling B lymphocyte behavior within bone marrow during development. Immunity (2004) 20:707-18. doi:10.1016/j.immuni.2004.05.001

46. Tokoyoda K, Zehentmeier S, Hegazy AN, Albrecht I, Grün JR, Löhning M, et al. Professional memory CD4+ T lymphocytes preferentially reside and rest in the bone marrow. Immunity (2009) 30:721-30. doi:10.1016/j. immuni.2009.03.015

47. Cawthorn WP, Scheller EL, Learman BS, Parlee SD, Simon BR, Mori H, et al. Bone marrow adipose tissue is an endocrine organ that contributes to increased circulating adiponectin during caloric restriction. Cell Metab (2014) 20:368-75. doi:10.1016/j.cmet.2014.06.003

48. Scheller EL, Rosen CJ. What's the matter with MAT? Marrow adipose tissue, metabolism, and skeletal health. Ann N Y Acad Sci (2014) 1311:14-30. doi:10.1111/nyas.12327

49. Fazeli PK, Horowitz MC, MacDougald OA, Scheller EL, Rodeheffer MS, Rosen CJ, et al. Marrow fat and bone - new perspectives. J Clin Endocrinol Metab (2013) 98:935-45. doi:10.1210/jc.2012-3634

50. Bianco P. Minireview: the stem cell next door: skeletal and hematopoietic stem cell "niches" in bone. Endocrinology (2011) 152:2957-62. doi:10.1210/ en.2011-0217

51. Caplan AI. Adult mesenchymal stem cells for tissue engineering versus regenerative medicine. J Cell Physiol (2007) 213:341-7. doi:10.1002/jcp.21200

52. Motyl KJ, McCabe LR. Leptin treatment prevents type I diabetic marrow adiposity but not bone loss in mice. JCell Physiol (2009) 218:376-84. doi: $10.1002 / j$ jp. 21608

53. Bethel M, Chitteti BR, Srour EF, Kacena MA. The changing balance between osteoblastogenesis and adipogenesis in aging and its impact on hematopoiesis. Curr Osteoporos Rep (2013) 11:99-106. doi:10.1007/s11914-0130135-6

54. Scheller EL, Doucette CR, Learman BS, Cawthorn WP, Khandaker S, Schell B, et al. Region-specific variation in the properties of skeletal adipocytes reveals regulated and constitutive marrow adipose tissues. Nat Commun (2015) 6:7808. doi: $10.1038 /$ ncomms 8808

55. Beghé C, Wilson A, Ershler WB. Prevalence and outcomes of anemia in geriatrics: a systematic review of the literature. Am JMed (2004) 116(Suppl):3S-10S. doi:10.1016/j.amjmed.2003.12.009

56. Gruver AL, Hudson LL, Sempowski GD. Immunosenescence of ageing. J Pathol (2007) 211:144-56. doi:10.1002/path.2104

57. Guralnik JM, Eisenstaedt RS, Ferrucci L, Klein HG, Woodman RC. Prevalence of anemia in persons 65 years and older in the United States: evidence for a high rate of unexplained anemia. Blood (2004) 104:2263-8. doi:10.1182/blood-2004-05-1812

58. Hakim FT, Gress RE. Immunosenescence: deficits in adaptive immunity in the elderly. Tissue Antigens (2007) 70:179-89. doi:10.1111/j.1399-0039.2007. 00891.x

59. Linton PJ, Dorshkind K. Age-related changes in lymphocyte development and function. Nat Immunol (2004) 5:133-9. doi:10.1038/ni1033

60. Emery JL, Follett GF. Regression of bone marrow haemopoiesis from the terminal digits in the foetus and infant. Br J Haematol (1964) 10:485-9. doi: 10.1111/j.1365-2141.1964.tb00725.x

61. Bigelow CL, Tavassoli M. Fatty involution of bone marrow in rabbits. Acta Anat (Basel) (1984) 118:60-4. doi:10.1159/000145823

62. Kricun ME. Red-yellow marrow conversion: its effect on the location of some solitary bone lesions. Skeletal Radiol (1985) 14:10-9. doi:10.1007/ BF00361188 
63. Tavassoli M, Watson LR, Khademi R. Retention of hemopoiesis in tail vertebrae of newborn rats. Cell Tissue Res (1979) 200:215-22. doi:10.1007/ BF00236414

64. Belaid-Choucair Z, Lepelletier Y, Poncin G, Thiry A, Humblet C, Maachi M, et al. Human bone marrow adipocytes block granulopoiesis through neuropilin-1-induced granulocyte colony-stimulating factor inhibition. Stem Cells (2008) 26:1556-64. doi:10.1634/stemcells.2008-0068

65. Belaid Z, Hubint F, Humblet C, Boniver J, Nusgens B, Defresne M-P. Differential expression of vascular endothelial growth factor and its receptors in hematopoietic and fatty bone marrow: evidence that neuropilin-1 is produced by fat cells. Haematologica (2005) 90:400-1.

66. Bilwani FA, Knight KL. Adipocyte-derived soluble factor(s) inhibits early stages of B lymphopoiesis. J Immunol (2012) 189:4379-86. doi:10.4049/ jimmunol.1201176

67. Kennedy DE, Knight KL. Inhibition of B lymphopoiesis by adipocytes and IL-1-producing myeloid-derived suppressor cells. J Immunol (2015) 195:2666-74. doi:10.4049/jimmunol.1500957

68. Balduino A, Hurtado SP, Frazão P, Takiya CM, Alves LM, Nasciutti L-E, et al. Bone marrow subendosteal microenvironment harbours functionally distinct haemosupportive stromal cell populations. Cell Tissue Res (2005) 319:255-66. doi:10.1007/s00441-004-1006-3

69. Cheng Y-H, Chitteti BR, Streicher DA, Morgan JA, Rodriguez-Rodriguez S, Carlesso N, et al. Impact of maturational status on the ability of osteoblasts to enhance the hematopoietic function of stem and progenitor cells. J Bone Miner Res (2011) 26:1111-21. doi:10.1002/jbmr.302

70. Chitteti BR, Cheng Y-H, Poteat B, Rodriguez-Rodriguez S, Goebel WS, Carlesso N, et al. Impact of interactions of cellular components of the bone marrow microenvironment on hematopoietic stem and progenitor cell function. Blood (2010) 115:3239-48. doi:10.1182/blood-2009-09-246173

71. Chitteti BR, Bethel M, Voytik-Harbin SL, Kacena MA, Srour EF. In vitro construction of $2 \mathrm{D}$ and $3 \mathrm{D}$ simulations of the murine hematopoietic niche. Methods Mol Biol (2013) 1035:43-56. doi:10.1007/978-1-62703-508-8_5

72. Naveiras O, Nardi V, Wenzel PL, Hauschka PV, Fahey F, Daley GQ. Bonemarrow adipocytes as negative regulators of the haematopoietic microenvironment. Nature (2009) 460:259-63. doi:10.1038/nature08099

73. Poncin G, Beaulieu A, Humblet C, Thiry A, Oda K, Boniver J, et al. Characterization of spontaneous bone marrow recovery after sublethal total body irradiation: importance of the osteoblastic/adipocytic balance. PLoS One (2012) 7:e30818. doi:10.1371/journal.pone.0030818

74. Zhu R-J, Wu M-Q, Li Z-J, Zhang Y, Liu K-Y. Hematopoietic recovery following chemotherapy is improved by BADGE-induced inhibition of adipogenesis. Int J Hematol (2013) 97:58-72. doi:10.1007/s12185-012-1233-4

75. Resnitzky P, Zipori D, Trainin N. Effect of neonatal thymectomy on hemopoietic tissue in mice. Blood (1971) 37:634-46.

76. Trainin N, Resnitzky P. Influence of neonatal thymectomy on cloning capacity of bone marrow cells in mice. Nature (1969) 221:1154-5. doi:10.1038/2211154a0

77. Bonomo AC, el-Cheikh MC, Borojevic R, Cavalcante LA, DosReis GA. Comparative analysis of splenic cell proliferation induced by interleukin 3 and by syngeneic accessory cells (syngeneic mixed leukocyte reaction): evidence that autoreactive T-cell functioning instructs hematopoietic phenomena. Cell Immunol (1990) 125:210-24. doi:10.1016/0008-8749(90)90075-3

78. Ho VT, Soiffer RJ. The history and future of T-cell depletion as graft-versushost disease prophylaxis for allogeneic hematopoietic stem cell transplantation. Blood (2001) 98:3192-204. doi:10.1182/blood.V98.12.3192

79. Martin PJ, Hansen JA, Torok-Storb B, Moretti L, Press O, Storb R, et al. Effects of treating marrow with a CD3-specific immunotoxin for prevention of acute graft-versus-host disease. Bone Marrow Transplant (1988) 3:437-44.

80. Kaufman CL, Colson YL, Wren SM, Watkins S, Simmons RL, Ildstad ST. Phenotypic characterization of a novel bone marrow-derived cell that facilitates engraftment of allogeneic bone marrow stem cells. Blood (1994) 84:2436-46.

81. Monteiro JP, Bonomo A. Linking immunity and hematopoiesis by bone marrow T cell activity. Braz J Med Biol Res (2005) 38:1475-86. doi:10.1590/ S0100-879X2005001000004

82. Banchereau J, Bazan F, Blanchard D, Brière F, Galizzi JP, van Kooten C, et al. The CD40 antigen and its ligand. Annu Rev Immunol (1994) 12:881-922. doi:10.1146/annurev.iy.12.040194.004313
83. Foy TM, Shepherd DM, Durie FH, Aruffo A, Ledbetter JA, Noelle RJ. In vivo CD40-gp39 interactions are essential for thymus-dependent humoral immunity. II. Prolonged suppression of the humoral immune response by an antibody to the ligand for CD40, gp39. J Exp Med (1993) 178:1567-75. doi:10.1084/jem.178.5.1567

84. Nonoyama S, Hollenbaugh D, Aruffo A, Ledbetter JA, Ochs HD. B cell activation via CD40 is required for specific antibody production by antigen-stimulated human B cells. J Exp Med (1993) 178:1097-102. doi:10.1084/ jem.178.3.1097

85. Solanilla A, Déchanet J, El Andaloussi A, Dupouy M, Godard F, Chabrol J, et al. CD40-ligand stimulates myelopoiesis by regulating flt3-ligand and thrombopoietin production in bone marrow stromal cells. Blood (2000) 95:3758-64.

86. Flores-Romo L, Björck P, Duvert V, van Kooten C, Saeland S, Banchereau J. CD40 ligation on human cord blood CD34+ hematopoietic progenitors induces their proliferation and differentiation into functional dendritic cells. J Exp Med (1997) 185:341-9. doi:10.1084/jem.185.2.341

87. Broxmeyer HE, Bruns HA, Zhang S, Cooper S, Hangoc G, McKenzie ANJ, et al. Th1 cells regulate hematopoietic progenitor cell homeostasis by production of Oncostatin M. Immunity (2002) 16:815-25. doi:10.1016/ S1074-7613(02)00319-9

88. Rådinger M, Sergejeva S, Johansson A-K, Malmhäll C, Bossios A, Sjöstrand M. Regulatory role of CD8+ T lymphocytes in bone marrow eosinophilopoiesis. Respir Res (2006) 7:83. doi:10.1186/1465-9921-7-83

89. Rådinger M, Bossios A, Alm A-S, Jeurink P, Lu Y, Malmhäll C, et al. Regulation of allergen-induced bone marrow eosinophilopoiesis: role of $\mathrm{CD} 4+$ and CD8+ T cells. Allergy (2007) 62:1410-8. doi:10.1111/j.1398-9995.2007. 01509.x

90. Schürch CM, Riether C, Ochsenbein AF. Cytotoxic CD8(+) T cells stimulate hematopoietic progenitors by promoting cytokine release from bone marrow mesenchymal stromal cells. Cell Stem Cell (2014) 14:460-72. doi:10.1016/j. stem.2014.01.002

91. Fleetwood AJ, Cook AD, Hamilton JA. Functions of granulocyte-macrophage colony-stimulating factor. Crit Rev Immunol (2005) 25:405-28. doi:10.1615/ CritRevImmunol.v25.i5.50

92. Hamilton JA, Anderson GP. GM-CSF biology. Growth Factors (2004) 22:225-31. doi:10.1080/08977190412331279881

93. Stanley E, Lieschke GJ, Grail D, Metcalf D, Hodgson G, Gall JA, et al. Granulocyte/macrophage colony-stimulating factor-deficient mice show no major perturbation of hematopoiesis but develop a characteristic pulmonary pathology. Proc Natl Acad Sci U S A (1994) 91:5592-6. doi:10.1073/ pnas.91.12.5592

94. Zhan Y, Cheers C. Haemopoiesis in mice genetically lacking granulocytemacrophage colony stimulating factor during chronic infection with Mycobacterium avium. Immunol Cell Biol (2000) 78:118-23. doi:10.1046/ j.1440-1711.2000.00891.x

95. Zhan Y, Lieschke GJ, Grail D, Dunn AR, Cheers C. Essential roles for granulocyte-macrophage colony-stimulating factor (GM-CSF) and G-CSF in the sustained hematopoietic response of Listeria monocytogenes-infected mice. Blood (1998) 91:863-9.

96. El-Behi M, Ciric B, Dai H, Yan Y, Cullimore M, Safavi F, et al. The encephalitogenicity of $\mathrm{T}(\mathrm{H}) 17$ cells is dependent on IL-1- and IL-23-induced production of the cytokine GM-CSF. Nat Immunol (2011) 12:568-75. doi:10.1038/ ni. 2031

97. Grifka-Walk HM, Giles DA, Segal BM. IL-12-polarized Th1 cells produce GM-CSF and induce EAE independent of IL-23. Eur J Immunol (2015) 45:2780-6. doi:10.1002/eji.201545800

98. McGeachy MJ. GM-CSF: the secret weapon in the $\mathrm{T}(\mathrm{H}) 17$ arsenal. Nat Immunol (2011) 12:521-2. doi:10.1038/ni.2044

99. McWilliams IL, Rajbhandari R, Nozell S, Benveniste E, Harrington LE. STAT4 controls GM-CSF production by both Th1 and Th17 cells during EAE. J Neuroinflammation (2015) 12:128. doi:10.1186/s12974-015-0351-3

100. Herndler-Brandstetter D, Flavell RA. Producing GM-CSF: a unique T helper subset? Cell Res (2014) 24:1379-80. doi:10.1038/cr.2014.155

101. Sheng W, Yang F, Zhou Y, Yang H, Low PY, Kemeny DM, et al. STAT5 programs a distinct subset of GM-CSF-producing $\mathrm{T}$ helper cells that is essential for autoimmune neuroinflammation. Cell Res (2014) 24:1387-402. doi: $10.1038 /$ cr.2014.154 
102. Cordeiro-Spinetti E, Taichman RS, Balduino AJ. The bone marrow endosteal niche: how far from the surface? J. Cell Biochem (2015) 116:6-11. doi:10.1002/ jcb. 24952

103. Krstić A, Santibanez JF, Okić I, Mojsilović S, Kocić J, Jovčić G, et al. Combined effect of IL-17 and blockade of nitric oxide biosynthesis on haematopoiesis in mice. Acta Physiol (2010) 199:31-41. doi:10.1111/j.1748-1716.2010.02082.x

104. Jovčić G, Bugarski D, Petakov M, Krstić A, Vlaški M, Stojanović N, et al. In vivo effects of interleukin-17 on haematopoietic cells and cytokine release in normal mice. Cell Prolif(2004) 37:401-12. doi:10.1111/j.1365-2184.2004.00322.x

105. Silva WA, Covas DT, Panepucci RA, Proto-Siqueira R, Siufi JLC, Zanette DL, et al. The profile of gene expression of human marrow mesenchymal stem cells. Stem Cells (2003) 21:661-9. doi:10.1634/stemcells.21-6-661

106. Mojsilović S, Jauković A, Santibañez JF, Bugarski D. Interleukin-17 and its implication in the regulation of differentiation and function of hematopoietic and mesenchymal stem cells. Mediators Inflamm (2015) 2015:470458. doi:10.1155/2015/470458

107. Fujisaki J, Wu J, Carlson AL, Silberstein L, Putheti P, Larocca R, et al. In vivo imaging of Treg cells providing immune privilege to the haematopoietic stem-cell niche. Nature (2011) 474:216-9. doi:10.1038/nature10160

108. Zhao E, Xu H, Wang L, Kryczek I, Wu K, Hu Y, et al. Bone marrow and the control of immunity. Cell Mol Immunol (2012) 9:11-9. doi:10.1038/ cmi.2011.47

109. Urbieta M, Barao I, Jones M, Jurecic R, Panoskaltsis-mortari A, Blazar BR, et al. Hematopoietic progenitor cell regulation by CD4+CD25+T cells. Blood (2010) 115:4934-43. doi:10.1182/blood-2009-04-218826

110. Takayanagi H, Ogasawara K, Hida S, Chiba T, Murata S, Sato K, et al. T-cell-mediated regulation of osteoclastogenesis by signalling crosstalk between RANKL and IFN-gamma. Nature (2000) 408:600-5. doi: $10.1038 / 35046102$

111. Mirantes C, Passegué E, Pietras EM. Pro-inflammatory cytokines: emerging players regulating HSC function in normal and diseased hematopoiesis. Exp Cell Res (2014) 329:248-54. doi:10.1016/j.yexcr.2014.08.017

112. Di Rosa F. T-lymphocyte interaction with stromal, bone and hematopoietic cells in the bone marrow. Immunol Cell Biol (2009) 87:20-9. doi:10.1038/ icb. 2008.84

113. Kristensen HB, Andersen TL, Marcussen N, Rolighed L, Delaisse JM. Increased presence of capillaries next to remodeling sites in adult human cancellous bone. J Bone Miner Res (2013) 28:574-85. doi:10.1002/jbmr.1760

114. Taichman RS, Wang Z, Shiozawa Y, Jung Y, Song J, Balduino A, et al. Prospective identification and skeletal localization of cells capable of multilineage differentiation in vivo. Stem Cells Dev (2010) 19:1557-70. doi:10.1089/scd.2009.0445

115. Jang M-G, Lee JY, Yang J-Y, Park H, Kim JH, Kim J-E, et al. Intermittent PTH treatment can delay the transformation of mature osteoblasts into lining cells on the periosteal surfaces. J Bone Miner Metab (2015). doi:10.1007/ s00774-015-0707-x

116. Raggatt LJ, Partridge NC. Cellular and molecular mechanisms of bone remodeling. J Biol Chem (2010) 285:25103-8. doi:10.1074/jbc.R109.041087

117. Anderson DM, Maraskovsky E, Billingsley WL, Dougall WC, Tometsko ME, Roux ER, et al. A homologue of the TNF receptor and its ligand enhance T-cell growth and dendritic-cell function. Nature (1997) 390:175-9. doi: $10.1038 / 36593$

118. Simonet W, Lacey D, Dunstan C, Kelley M, Chang M-S, Lüthy R, et al. Osteoprotegerin: a novel secreted protein involved in the regulation of bone density. Cell (1997) 89:309-19. doi:10.1016/S0092-8674(00)80209-3

119. Li Y, Toraldo G, Li A, Yang X, Zhang H, Qian WP, et al. B cells and T cells are critical for the preservation of bone homeostasis and attainment of peak bone mass in vivo. Blood (2007) 109:3839-48. doi:10.1182/blood-2006-07-037994

120. Yun TJ, Chaudhary PM, Shu GL, Frazer JK, Ewings MK, Schwartz SM, et al. OPG/FDCR-1, a TNF receptor family member, is expressed in lymphoid cells and is up-regulated by ligating CD40. J Immunol (1998) 161:6113-21.

121. Yun TJ, Tallquist MD, Aicher A, Rafferty KL, Marshall AJ, Moon JJ, et al. Osteoprotegerin, a crucial regulator of bone metabolism, also regulates $\mathrm{B}$ cell development and function. J Immunol (2001) 166:1482-91. doi:10.4049/ jimmunol.166.3.1482

122. Dougall WC, Glaccum M, Charrier K, Rohrbach K, Brasel K, De Smedt T, et al. RANK is essential for osteoclast and lymph node development. Genes Dev (1999) 13:2412-24. doi:10.1101/gad.13.18.2412
123. Kong YY, Yoshida H, Sarosi I, Tan HL, Timms E, Capparelli C, et al. OPGL is a key regulator of osteoclastogenesis, lymphocyte development and lymphnode organogenesis. Nature (1999) 397:315-23. doi:10.1038/16852

124. Rossi SW, Kim M-Y, Leibbrandt A, Parnell SM, Jenkinson WE, Glanville SH, et al. RANK signals from CD4(+)3(-) inducer cells regulate development of Aire-expressing epithelial cells in the thymic medulla. J Exp Med (2007) 204:1267-72. doi:10.1084/jem.20062497

125. Fata JE, Kong YY, Li J, Sasaki T, Irie-Sasaki J, Moorehead RA, et al. The osteoclast differentiation factor osteoprotegerin-ligand is essential for mammary gland development. Cell (2000) 103:41-50. doi:10.1016/S0092-8674(00) 00103-3

126. Jones DH, Nakashima T, Sanchez OH, Kozieradzki I, Komarova SV, Sarosi I, et al. Regulation of cancer cell migration and bone metastasis by RANKL. Nature (2006) 440:692-6. doi:10.1038/nature04524

127. Roggia C, Gao Y, Cenci S, Weitzmann MN, Toraldo G, Isaia G, et al. Up-regulation of TNF-producing T cells in the bone marrow: a key mechanism by which estrogen deficiency induces bone loss in vivo. Proc Natl Acad Sci U S A (2001) 98:13960-5. doi:10.1073/pnas.251534698

128. Lee S-K, Kadono Y, Okada F, Jacquin C, Koczon-Jaremko B, Gronowicz G, et al. T lymphocyte-deficient mice lose trabecular bone mass with ovariectomy. J Bone Miner Res (2006) 21:1704-12. doi:10.1359/jbmr.060726

129. Charles JF, Ermann J, Aliprantis AO. The intestinal microbiome and skeletal fitness: connecting bugs and bones. Clin Immunol (2015) 159:163-9. doi:10.1016/j.clim.2015.03.019

130. Sjögren K, Engdahl C, Henning P, Lerner UH, Tremaroli V, Lagerquist MK, et al. The gut microbiota regulates bone mass in mice. J Bone Miner Res (2012) 27:1357-67. doi:10.1002/jbmr.1588

131. Kong YY, Feige U, Sarosi I, Bolon B, Tafuri A, Morony S, et al. Activated $\mathrm{T}$ cells regulate bone loss and joint destruction in adjuvant arthritis through osteoprotegerin ligand. Nature (1999) 402:304-9. doi:10.1038/46303

132. Kim N, Odgren PR, Kim DK, Marks SC, Choi Y. Diverse roles of the tumor necrosis factor family member TRANCE in skeletal physiology revealed by TRANCE deficiency and partial rescue by a lymphocyte-expressed TRANCE transgene. Proc Natl Acad Sci U S A (2000) 97:10905-10. doi:10.1073/ pnas. 200294797

133. Sato K, Suematsu A, Okamoto K, Yamaguchi A, Morishita Y, Kadono Y, et al. Th17 functions as an osteoclastogenic helper $\mathrm{T}$ cell subset that links $\mathrm{T}$ cell activation and bone destruction. J Exp Med (2006) 203:2673-82. doi:10.1084/jem.20061775

134. Takayanagi H. Osteoimmunology and the effects of the immune system on bone. Nat Rev Rheumatol (2009) 5:667-76. doi:10.1038/nrrheum.2009.217

135. Arron JR, Choi Y. Bone versus immune system. Nature (2000) 408:535-6 doi: $10.1038 / 35046196$

136. Takayanagi H. Osteoimmunology: shared mechanisms and crosstalk between the immune and bone systems. Nat Rev Immunol (2007) 7:292-304. doi: $10.1038 /$ nri2062

137. Takayanagi H. New developments in osteoimmunology. Nat Rev Rheumatol (2012) 8:684-9. doi:10.1038/nrrheum.2012.167

138. Monteiro AC, Leal AC, Gonçalves-Silva T, Mercadante ACT, Kestelman F, Chaves SB, et al. T cells induce pre-metastatic osteolytic disease and help bone metastases establishment in a mouse model of metastatic breast cancer. PLoS One (2013) 8:e68171. doi:10.1371/journal.pone.0068171

139. Mundy GR. Metastasis to bone: causes, consequences and therapeutic opportunities. Nat Rev Cancer (2002) 2:584-93. doi:10.1038/nrc867

140. Roodman GD. Mechanisms of bone metastasis. N Engl J Med (2004) 350:1655-64. doi:10.1056/NEJMra030831

141. Horton JE, Raisz LG, Simmons HA, Oppenheim JJ, Mergenhagen SE. Bone resorbing activity in supernatant fluid from cultured human peripheral blood leukocytes. Science (1972) 177:793-5. doi:10.1126/science.177.4051.793

142. Dewhirst FE, Stashenko PP, Mole JE, Tsurumachi T. Purification and partial sequence of human osteoclast-activating factor: identity with interleukin 1 beta. J Immunol (1985) 135:2562-8.

143. Merad M. The dendritic cellelineage: ontogeny and function of dendritic cells and their subsets in the steady state and the inflamed setting. Ann Rev Imunnol (2013) 31:563-604. doi:10.1146/annurev-immunol-020711074950

144. Alnaeeli M, Penninger JM, Teng YA. Immune interactions with CD4+ cells promote the development of functional osteoclasts from murine 
CD11c+ dendritic cells. JImmunol (2006) 177:3314-26. doi:10.4049/ jimmunol.177.5.3314

145. Rivollier A, Mazzorana M, Tebib J, Piperno M, Aitsiselmi T, RabourdinCombe $\mathrm{C}$, et al. Immature dendritic cell transdifferentiation into osteoclasts: a novel pathway sustained by the rheumatoid arthritis microenvironment. Blood (2004) 104:4029-37. doi:10.1182/blood-2004-01-0041

146. Speziani C, Rivollier A, Gallois A, Coury F, Mazzorana M, Azocar O, et al. Murine dendritic cell transdifferentiation into osteoclasts is differentially regulated by innate and adaptive cytokines. Eur I Immunol (2007) 37:747-57. doi:10.1002/eji.200636534

147. Li H, Hong S, Qian J, Zheng Y, Yang J, Yi Q. Crosstalk between the bone and immune systems: osteoclasts function as antigen-presenting cells and activate CD4+ and CD8+ T cells. Blood (2010) 116:210-7. doi:10.1182/ blood-2009-11-255026

148. Alnaeeli M, Teng Y-TA. Dendritic cells differentiate into osteoclasts in bone marrow microenvironment in vivo. Blood (2009) 113:264-5. doi:10.1182/ blood-2008-09-180836

149. Alnaeeli M, Park J, Mahamed D, Penninger JM, Teng Y-T. Dendritic cells at the osteo-immune interface: implications for inflammation-induced bone loss. J Bone Miner Res (2007) 22:775-80. doi:10.1359/jbmr.070314

150. Coury F, Annels N, Rivollier A, Olsson S, Santoro A, Speziani C, et al. Langerhans cell histiocytosis reveals a new IL-17A-dependent pathway of dendritic cell fusion. Nat Med (2008) 14:81-7. doi:10.1038/ $\mathrm{nm} 1694$

151. Tran Janco JM, Lamichhane P, Karyampudi L, Knutson KL. Tumor-infiltrating dendritic cells in cancer pathogenesis. JImmunol (2015) 194:2985-91. doi:10.4049/jimmunol.1403134

152. Badalian-Very G, Vergilio J-A, Degar BA, Rodriguez-Galindo C, Rollins BJ. Recent advances in the understanding of Langerhans cell histiocytosis. $\mathrm{Br}$ J Haematol (2012) 156:163-72. doi:10.1111/j.1365-2141.2011.08915.x

153. Lourda M, Olsson-Åkefeldt S, Gavhed D, Björnfot S, Clausen N, Hjalmars U, et al. Detection of IL-17A-producing peripheral blood monocytes in
Langerhans cell histiocytosis patients. Clin Immunol (2014) 153:112-22. doi:10.1016/j.clim.2014.04.004

154. Grosjean F, Nasi S, Schneider P, Chobaz V, Liu A, Mordasini V, et al. Dendritic cells cause bone lesions in a new mouse model of histiocytosis. PLoS One (2015) 10:e0133917. doi:10.1371/journal.pone.0133917

155. Feuerer M, Beckhove P, Garbi N, Mahnke Y, Limmer A, Hommel M, et al. Bone marrow as a priming site for T-cell responses to blood-borne antigen. Nat Med (2003) 9:1151-7. doi:10.1038/nm914

156. Kollet O, Dar A, Shivtiel S, Kalinkovich A, Lapid K, Sztainberg Y, et al. Osteoclasts degrade endosteal components and promote mobilization of hematopoietic progenitor cells. Nat Med (2006) 12:657-64. doi:10.1038/ nm1417

157. Mansour A, Anginot A, Mancini SJC, Schiff C, Carle GF, Wakkach A, et al. Osteoclast activity modulates B-cell development in the bone marrow. Cell Res (2011) 21:1102-15. doi:10.1038/cr.2011.21

158. Moutsatsos IK, Turgeman G, Zhou S, Kurkalli BG, Pelled G, Tzur L, et al. Exogenously regulated stem cell-mediated gene therapy for bone regeneration. Mol Ther (2001) 3:449-61. doi:10.1006/mthe.2001.0291

159. Matzinger P, Kamala T. Tissue-based class control: the other side of tolerance. Nat Rev Immunol (2011) 11:221-30. doi:10.1038/nri2940

Conflict of Interest Statement: The authors declare that the research was conducted in the absence of any commercial or financial relationships that could be construed as a potential conflict of interest.

Copyright (๑ 2016 Bonomo, Monteiro, Gonçalves-Silva, Cordeiro-Spinetti, Galvani and Balduino. This is an open-access article distributed under the terms of the Creative Commons Attribution License (CC BY). The use, distribution or reproduction in other forums is permitted, provided the original author(s) or licensor are credited and that the original publication in this journal is cited, in accordance with accepted academic practice. No use, distribution or reproduction is permitted which does not comply with these terms. 